\title{
Structure-Based Design and Characterization of Novel Platforms for Ricin and Shiga Toxin Inhibition
}

\author{
Darcie J . Miller, ${ }^{\dagger}$ Kabyadi Ravikumar, ${ }^{\ddagger}$ Huafeng Shen, ${ }^{\ddagger}$ J ung-Keun Suh, ${ }^{\dagger}$ Sean M. Kerwin, ${ }^{\ddagger}$ and \\ J on D. Robertus*,t \\ Department of Chemistry and Biochemistry and Division of Medicinal Chemistry, College of Pharmacy, \\ University of Texas, Austin, Texas 778712
}

Received April 25, 2001

\begin{abstract}
Ribosome inhibiting proteins, RIPs, are a widespread family of toxic enzymes. Ricin is a plant toxin used as a poison and biological warfare agent; shiga toxin is a homologue expressed by pathogenic strains of $E$. coli. There is interest in creating effective antidote inhibitors to this class of enzymes. RIPs act by binding and hydrolyzing a specific adenine base from rRNA. Previous virtual screens revealed that pterins could bind in the specificity pocket of ricin and inhibit the enzyme. In this paper we explore a range of compounds that could serve as better platforms for inhibitor design. This establishes the importance of key hydrogen bond donors and acceptors for active-site complementarity. 8-Methyl-9-oxoguanine is a soluble compound that has the best inhibitory properties of any platform tested. The X-ray structure of this complex revealed that the inhibitor binds in an unexpected way that provides insight for future design. Several inhibitors of ricin were also shown to be inhibitors of shiga toxin, suggesting this program has the potential to develop effective antidotes to an important form of food poisoning.
\end{abstract}

\section{Introduction}

Ribosome inhibiting proteins (RIPS) are found in a variety of higher plants and in certain pathogenic bacteria. ${ }^{1}$ These toxins are $\mathrm{N}$-glycosidases that inactivate ribosomes by depurinating a key adenine from an invariant sequence of rRNA. ${ }^{2,3}$ The most well studied of these RIPs is ricin, a heterodimeric toxin isolated from Ricinus communis. ${ }^{4,5}$ Ricin has an $L D_{50}$ of $\sim 1 \mu \mathrm{g} /$ $\mathrm{kg}$ body weight for mice, rats, and dogs and is 10 times more potent against rabbits. ${ }^{1}$ The toxic dose for humans is likely to be in the $0.1-1.0 \mu \mathrm{g} / \mathrm{kg}$ range, depending on the mode of administration, and ranks it among the most toxic substances known.

Ricin was used in the famous "umbrella tip" assassination of Georgy Markov ${ }^{6}$ and was also used in an unsuccessful attempt to poison the famous Soviet dissident Alexander Solzhenitsyn. ${ }^{7}$ Ricin was prepared by a militant antitax group, which planned to poison IRS personnel ${ }^{8}$ and has continued to be used in attempted murders $^{9}$ and terrorist acts. ${ }^{10}$ There is therefore an interest in developing an effective antidote to the toxin.

Ricin inhibitors may also be useful against the homologous proteins Shiga toxin (ST) and Shiga-like toxin type 1 (Stx1). ST is produced by Shigella dysenteriae type 1, the organism first described by Kiyoshi Shiga following the 1896 dysentery epidemic in Japan. ${ }^{11}$ Pathogenic strains of E. coli, such as the infamous O157: H7 serotype, express Stx1. These enterohemmorhagic E. coli are implicated in a number of diseases such as hemorrhagic colitis, neonatal and adult diarrhea, and hemolytic uremic syndrome. Only one conservative

* To whom correspondence should be addressed. Phone: (512) 471 3175. Fax: (512) 471-8696. E-mail: jrobertus@mail.utexas.edu. † Department of Chemistry and Biochemistry.

₹ Division of Medicinal Chemistry, College of Pharmacy. amino acid change in the catalytic $A$ subunit distinguishes ST from Stx1. ${ }^{12}$ These bacterial enzymes catalyze the same reaction as RTA and possess significant similarity in three-dimensional structure. ${ }^{13,14}$ RTA inhibitors are also being tested against the bacterial enzyme Stx 1 and may lead to the design of drugs useful in treating enterbacterial outbreaks. ${ }^{15}$

The X-ray structure of intact heterodimeric ricin is known, ${ }^{16}$ and the enzymatic $A$ chain of ricin, called RTA, has been described at higher resolution. ${ }^{14,17,18}$ Sitedirected mutagenesis, kinetic studies, ${ }^{19,20}$ and the binding of substrate analogues to the crystallaline RTA ${ }^{21}$ have provided crucial information about the mechanism of action. The adenine base binds in a specificity pocket between the side chains of tyrosines 80 and 123 and makes specific hydrogen bonds with the protein. When adenine binds into the specificity site of ricin, it must displace the side chain of Tyr 80 from the pocket, rotating it roughly $45^{\circ}$ to a place where it stacks with the substrate ring. In the catalytic mechanism, Arg 180 appears to act as an acid to partially protonate the leaving base and Glu 177 stabilizes the transition state or serves as a base to activate the attacking water molecule.

The parameters of the RTA structure and mechanism all owed a computerized virtual screen to be carried out that identified pteroic acid (PTA) as a likely inhibitor of the toxin. Subsequent kinetic measurements confirmed that PTA was a modest inhibitor of RTA action, and the X-ray structure of the complex confirmed that the proposed mode of binding was very similar to the observed binding. ${ }^{22}$ Pteroic acid is poorly soluble and has limited value as a lead compound for the design of effective inhibitors and useful RIP antidotes. Energy calculations were used to investigate likely binding modes of other potential inhibitors, including tautomers 
A.

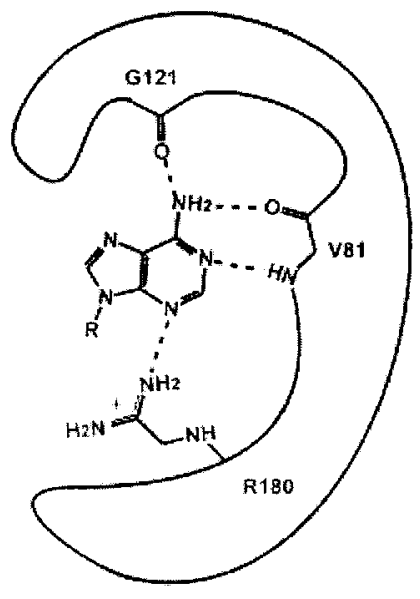

B.

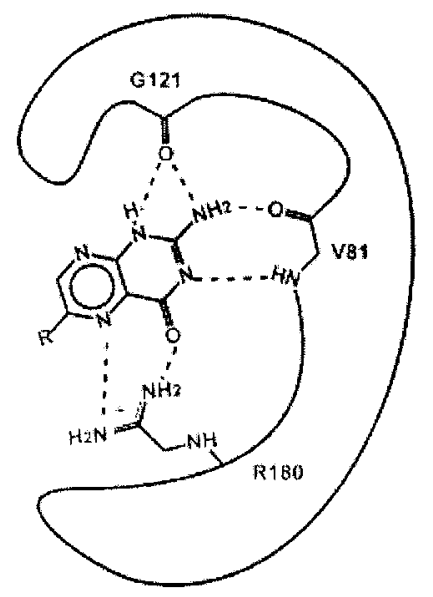

C.

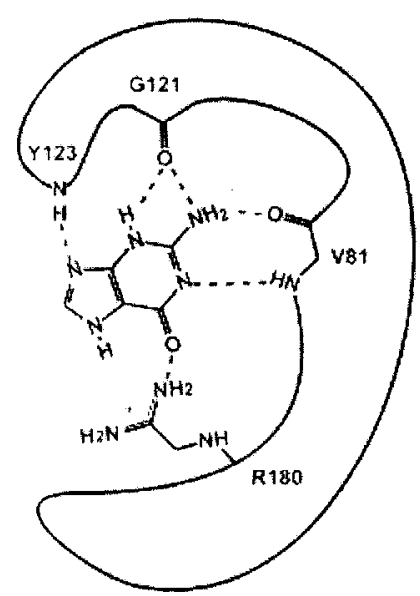

Figure 1. Cartoon representation of the interactions between the adenine moi ety of the bound dinucleotide $A p G^{21}(A)$, the pterin moiety of pteroic acid (B), and the specificity pocket of RTA. The predicted binding of guanine to the RTA active site is shown in panel C.

\section{Scheme 1}

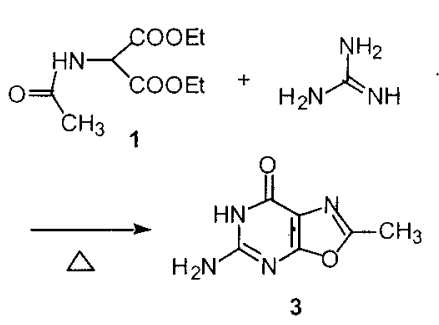

of pterins and guanine. ${ }^{23}$ These calculations suggested that guanine-like compounds could interact strongly with the RTA specificity pocket, and this served as a basis for the design and synthesis of a series of inhibitors described in this work. Figure 1 shows a cartoon representation of the interactions made between the pterin moiety of pteroic acid and the specificity pocket of RTA. Our goal is to design inhibitors that will make favorable interactions with the functional groups in the active site and still possess improved solubility.

\section{Chemistry}

Most of the heterocyclic compounds evaluated here are commercially available or have been previously reported in the literature. The preparation of new compounds is briefly outlined here. The 5-amino-6Hoxazollo[5,4-d]pyrimin-7-one ring system (9-oxoguanine, e.g., 3) is relatively unexplored. ${ }^{24,25}$ We prepared 5-amino2-methyl-7-oxooxazol o[5,4-d]pyrimidine (3) by condensation of acetamidomal onate (1) with guanidine hydrochloride in sodium ethoxide/ethanol to afford 5-acetylamino-2-amino-4,6-dihydroxypyrimidine (2) in 89\% yield. Heating 5-acetylamino-2-amino-4,6-dihydroxy pyrimidine to $280-300{ }^{\circ} \mathrm{C}$ under vacuum afforded 5-amino-2methyl-6H-oxooxazol o[5,4-d]pyrimidin-7-one (3, Scheme 1). The pyridothiadiazine ring system (e.g., 5) can be easily accessed from the corresponding amino sulfonamide. ${ }^{26}$ Heating a mixture of 3-aminopyridine-2-sulfonamide (4) and guanidine carbonate afforded 3-aminopyridothiadiazine (5, Scheme 2 ) in 31\% yield.

Pyrrolo[2,3-d]pyrimidines (7-deazapurines, e.g., 8) bearing pendent groups can be easily obtained from

\section{Scheme 2}

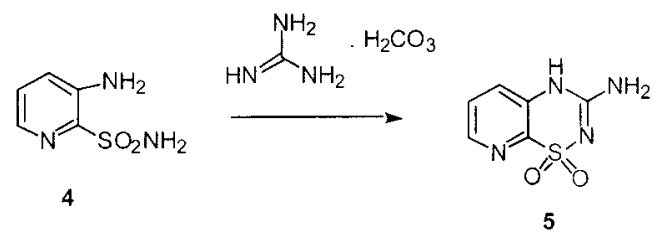

Manich reaction of these compounds with various secondary amines. ${ }^{27}$ 5-(N,N-dibenzyl)aminomethyl-2octanoylaminopyrrolo[2,3-d]pyrimidin-4(3H )-one (6) was prepared is this way according to the literature procedure. Heating 6 with an excess of methyl 4-aminobenzoate in a sealed tube afforded the substitution product 5-(4'-carbomethoxyphenylaminomethyl)-2-octanoylaminopyrrolo[2,3-d]pyrimidin-4(3H)-one (7), which was hydrolyzed to afford 5-(4'-carboxyphenylaminomethyl)-2-octanoylaminopyrrolo[2,3-d]pyrimidin-4(3H)-one (8, Scheme 3).

\section{Results and Discussion}

A variety of aromatic compounds, shown in Table 1 , were tested as inhibitors of ricin. Ricin recognizes the adenine base of its natural rRNA substrate and binds bicyclic pterin rings, as seen in the inhibitors PTA and neopterin. ${ }^{22}$ Even so, we felt it would be reasonable to explore the potential of singlering compounds as inhibitors. One of the better single-ring inhibitors tested was 2,5-diamino-4,6-dihydroxypyrimidine, which possessed many of the hydrogen bonding attributes of the known pterin-based inhibitors. Its I $\mathrm{C}_{50}$ is $2.2 \mathrm{mM}$, similar to that seen for neopterin. ${ }^{22}$ To explore its mode of binding, 


\section{Scheme 3}

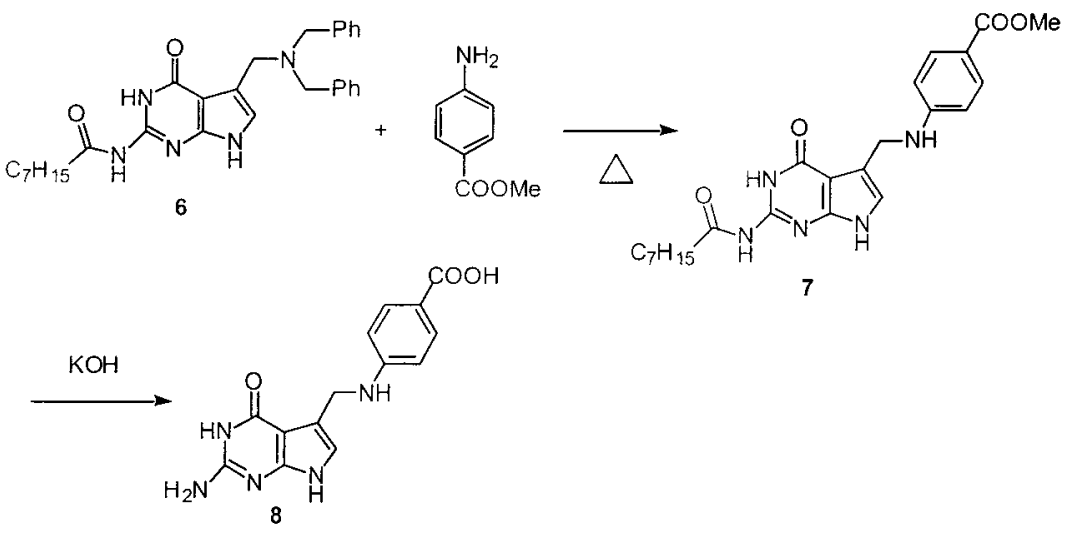

the inhibitor was cocrystallized with RTA and X-ray data were collected to $2.8 \AA$ resolution. Despite being grown under conditions that typically yield monoclinic crystals, the crystals of the complex were triclinic with $\mathrm{a}=42.07 \AA, \mathrm{b}=65.95 \AA, \mathrm{c}=50.81 \AA, \alpha=93.90^{\circ}, \beta=$ $112.4^{\circ}, \gamma=84.43^{\circ}$ and two molecules, referred to here as $A$ and $B$, form the asymmetric unit. A summary of crystallographic data for this, and other inhibitor complexes, is shown in Table 2.

Molecule A binds the ligand, but molecule B does not. In addition, the shift from a monoclinic to a tridinic cell alters symmetry contacts between the protein molecules, which perturbs the conformation of several residues far from the active site. These include Arg 39, His 40, Glu 41, Thr 159, Asn 222, and GIn 223 in molecule A. Increased disorder eliminated electron density for Arg 39, and side chain density was no longer visible for His 40, Glu 41, and Thr. Even so, the overall conformation of RTA in the two crystals formed is very similar; the $\mathrm{C} \alpha$ carbon positions of the triclinic protein differ from those of the monodinic form by an rms value of $0.09 \AA$ for molecule $A$ and $0.07 \AA$ for molecule $B$. Molecules $A$ and $B$ vary between themselves mostly in their surface-exposed $C$ termini. The two molecules have an rms deviation of $0.07 \AA$ for $\mathrm{C} \alpha$ carbons.

The binding of the inhibitor 2,5-diamino-4,6-dihydroxypyrimidine (DDP) to the active site of RTA is shown in Figure 2. Unlike adenineanalogues, or pterins, DDP does not displace the side chain of Tyr 80 from its apoenzyme conformation and fails to open the specificity pocket, that is, the portion of the active site that specifically binds adenine. Instead, the inhibitor is stacked against the side chain of Tyr 80 in its closed conformation. The interaction apparently stabilizes the inactive form of RTA, freezing the Tyr 80 side chain in a position that blocks access to the specificity pocket and thereby prevents the substrate adenine from being recognized.

Because the single-ring inhibitor did not enter the RTA specificity pocket, it was precluded from making many specific interactions there and limited its usefulness as a platform for further experiments. As a consequence, we discontinued work on single-ring inhibitors.

The specificity pocket of RTA is lined with hydrogen bond donors and acceptors, particularly those from the backbone atoms of Gly 121 and Val 80 shown in Figure 1 , which guarantee the binding of adenine in the context of natural RNA. These groups can be subverted by other ring systems, and we have previously seen that the pterin moiety of PTA and neopterin can be oriented to make more and stronger interactions than does adenine. Neither adenine nor adenosine inhibits ricin, whereas PTA is a modest inhibitor. We carried out a systematic survey of compounds with differing patterns of hydrogen bond donors and acceptors to try to maximize these interactions. Computer modeling ${ }^{23}$ suggested that 3-aminopyridothiadiazine would preserve many of the specific interactions observed for pterins but would juxtapose a partially negative sulfone with Arg 180 of RTA. Despite the suggestions of modeling, this compound, in fact, was not an inhibitor of the enzyme (Table 1).

Because the pterin-like compounds were poorly soluble, we also undertook a study of guanine-like compounds. We had predicted from energy calculations that guanine, rotated roughly $180^{\circ}$ around the long of the purine base (a line from C8 to the midpoint of the N 1-C2 bond) with respect to the adenine orientation, could bind and inhibit RTA. ${ }^{23}$ As shown in Table 1 , guanine has an I $C_{50}$ of $0.9 \mathrm{mM}$. We also tested xanthine as an inhibitor. It had an $\mathrm{IC}_{50}$ of $3.6 \mathrm{mM}$, confirming the importance of the exocyclic amino group at the 2-position of the base. This ami no group is expected to donate hydrogen bonds to the carbonyl oxygens of Val 81 and Gly 121. Subsequent inhibitor candidates would all preserve the pyrimidine ring structure seen in guanine (that is, 2-amino6-hydroxypyridine).

Table 1 shows the $\mathrm{I}_{50}$ values for a number of bicyclic compounds that retained the six-membered ring of guanine. These include 8-mercaptoguanine, thiazol pyrimidine, 9-deazagunaine (9DG), 7-deazaguanine (7DG), 8-methyl-7-deazaguanine, and 8-methyl-9-oxoguanine (9OG). The I $C_{50}$ values for these compounds range from $2.8 \mathrm{mM}$ for 7DG to $0.4 \mathrm{mM}$ for 90G. The latter compound has the best $\mathrm{IC}_{50}$ of any platform compound we have measured, by a slight margin, but more importantly is very much more soluble in water. Since it had the potential to bea useful molecular platform for future inhibitor design, we attempted to solve the X-ray structure of the complex of this inhibitor with RTA.

Soaking RTA crystals in 90G caused them to crack. Useful crystals were formed by crystallizing the enzyme in the presence of the inhibitor. In addition, only cryocooled cocrystals survived exposure to X-rays. As shown in Table 1, the crystals were not perfectly isomorphous with native RTA crystals, and their dif- 
Table 1. RTA Inhibitors

\begin{tabular}{|c|c|c|c|}
\hline 2D Structure & Name & $I_{50}$ (RTA) & Resolution $(\AA)$ \\
\hline & $\begin{array}{l}\text { Pteroic acid } \\
\text { (PTA) }\end{array}$ & $0.6 \mathrm{mM}$ & 2.30 \\
\hline & $\begin{array}{l}\text { 2,5-diamino-4,6- } \\
\text { dihydroxypyrimidine } \\
\text { (DDP) }\end{array}$ & $2.2 \mathrm{mM}$ & 2.80 \\
\hline & $\begin{array}{c}\text { 3-amino-pyridothiadiazine- } \\
\text { 1,1-dioxide }\end{array}$ & No inhibition & $\mathrm{N} / \mathrm{A}$ \\
\hline & $\begin{array}{l}\text { 2-amino-6-hydroxypurine } \\
\text { (guanine) }\end{array}$ & $0.9 \mathrm{mM}$ & $\mathrm{N} / \mathrm{A}$ \\
\hline & $\begin{array}{l}\text { 2,6-dihydroxypurine } \\
\text { (xanthine) }\end{array}$ & $3.6 \mathrm{mM}$ & $\mathrm{N} / \mathrm{A}$ \\
\hline & $\begin{array}{l}\text { 2-amino-6-hydroxy-8- } \\
\text { mercaptopurine } \\
\text { (8-mercaptoguanine) }\end{array}$ & $0.56 \mathrm{mM}$ & $N / A$ \\
\hline & Thiazolopyrimidine & $2.0 \mathrm{mM}$ & $\mathrm{N} / \mathrm{A}$ \\
\hline & $\begin{array}{l}\text { 2-amino-3,4-dihydro-4-oxo- } \\
9 \mathrm{H} \text {-pyrrolo[2,3-d]-pyrimidine } \\
\text { (9DG) }\end{array}$ & $1.4 \mathrm{mM}$ & 2.60 \\
\hline & $\begin{array}{c}\text { 2-amino-3,4-dihydro-4-oxo- } \\
\text { 7H-pyrrolo[2,3-d]-pyrimidine } \\
\text { (7DG) }\end{array}$ & $2.8 \mathrm{mM}$ & 2.80 \\
\hline & $\begin{array}{c}\text { 2-amino-6-methyl-3,4- } \\
\text { dihydro-4-oxo-7H-pyrrolo[2,3- } \\
\text { d]-pyrimidine } \\
\text { (8-methyl-7-deazaguanine) }\end{array}$ & $2.1 \mathrm{mM}$ & N/A \\
\hline & $\begin{array}{c}\text { 5-amino-2-methyl-6H- } \\
\text { oxooxazolo[5,4d]pyrimidin-7- } \\
\text { one } \\
(90 \mathrm{G})\end{array}$ & $\overline{0.40 \mathrm{mM}}$ & 3.0 \\
\hline & $\begin{array}{l}\mathrm{N}-4-[2-(2-a m i n o-4(3 \mathrm{H}) \text {-oxo- } \\
7 \mathrm{H} \text {-pyrrolo[2,3-d]pyrimidin-6- } \\
\text { yl)ethyl]benzoic acid }\end{array}$ & $0.60 \mathrm{mM}$ & N/A \\
\hline & $\begin{array}{c}\text { 5-(4- } \\
\text { carboxyphenylaminomethyl)2- } \\
\text { octanoylaminopyrrolo[2,3- } \\
\text { d]pyrimidin- } 4(3 \mathrm{H}) \text {-one }\end{array}$ & $0.70 \mathrm{mM}$ & N/A \\
\hline
\end{tabular}

fraction was limited to $3.1 \AA$, suggesting poor crystal order. Even so, an interpretable electron density map was produced, as shown in Figure 3.

The binding orientation of $90 \mathrm{G}$ in the RTA active site was unexpected. Although many of the anticipated pterin-like hydrogen bonds were formed, they were made in novel ways. This is illustrated in Figure 4 where the orientation of $90 \mathrm{G}$ is compared with that of the pterin ring of PTA. The orientation of $90 \mathrm{G}$ can be roughly generated from PTA by flipping the bicyclic ring system $180^{\circ}$ around the long axis and then rotating it $60^{\circ}$ around an axis normal to the page. In both cases the exocyclic amine group sits in a pocket where it donates hydrogen bonds to the carbonyl groups of $\mathrm{Val}$ 81 and Gly 121. At the same time a ring nitrogen accepts a hydrogen bond from the amido group of Val 81. These are key interactions also preserved in the binding of adenine substrate and formycin. ${ }^{21}$

Pterin-based inhibitors assume a high-energy tautomer to make the interactions described above and an additional one arising as follows. The low-energy tautomer of pterin has a hydrogen on N3, but this would 
Table 2. Data Collection and Refinement Statistics for RTA/I nhibitor Complexes ${ }^{\mathrm{a}}$

\begin{tabular}{|c|c|c|c|c|}
\hline & 7DG·RTA & 9DG·RTA & 9OG.RTA & DDP·RTA \\
\hline a $(\AA)$ & 42.77 & 42.70 & 43.04 & 42.07 \\
\hline $\mathrm{b}(\AA)$ & 68.27 & 68.41 & 67.84 & 65.95 \\
\hline$c(\AA)$ & 49.93 & 50.16 & 49.68 & 50.81 \\
\hline$\alpha(\mathrm{deg})$ & & & & 93.90 \\
\hline$\beta$ (deg) & 112.9 & 112.8 & 113.26 & 112.4 \\
\hline$\gamma(\mathrm{deg})$ & & & & 84.43 \\
\hline space group & $\mathrm{P} 2_{1}$ & $\mathrm{P} 2_{1}$ & $\mathrm{P} 2_{1}$ & P1 \\
\hline resolution $(\AA)$ & 2.8 & 2.6 & 3.1 & 2.8 \\
\hline no. obsd (unique) & $12592(6621)$ & 16235 (8286) & $15067(5350)$ & 30838 (12 362) \\
\hline $\mathrm{R}_{\text {merge }}$ (last shell) (\%) & $7.1(19.2)$ & $8.4(28.8)$ & $10.3(15.92)$ & $8.8(24.6)$ \\
\hline $\mathrm{I} / \delta_{\mathrm{I}}$ (last shell) & $9.93(3.57)$ & $9.30(2.71)$ & $10.15(4.08)$ & $7.43(2.68)$ \\
\hline completeness (last shell) (\%) & 94.7 (93.5) & $94.0(87.2)$ & $95.6(95.4)$ & $91.6(83.7)$ \\
\hline $\mathrm{R}_{\text {work }}(\%)$ & 20.2 & 22.2 & 24.7 & 22.5 \\
\hline$R_{\text {free }}(\%)$ & 27.3 & 29.3 & 30.6 & 28.3 \\
\hline rms deviation $(\AA$, deg $)$ & $0.004,1.341$ & $0.004,1.196$ & $0.004,1.210$ & $0.004,1.108$ \\
\hline
\end{tabular}

${ }^{a}$ Each column contains crystallographic parameters for a different inhibitor complex with RTA. 7DG represents the complex with 7-deazaguanine, 9DG is 9-deazaguanine, 9OG is 8-methyl-9-oxoguanine, and DDP is 2,5-diamino-4,6-dihydroxypyrimidine. Coordinates for these four complexes have been deposited in the Protein Data Bank.
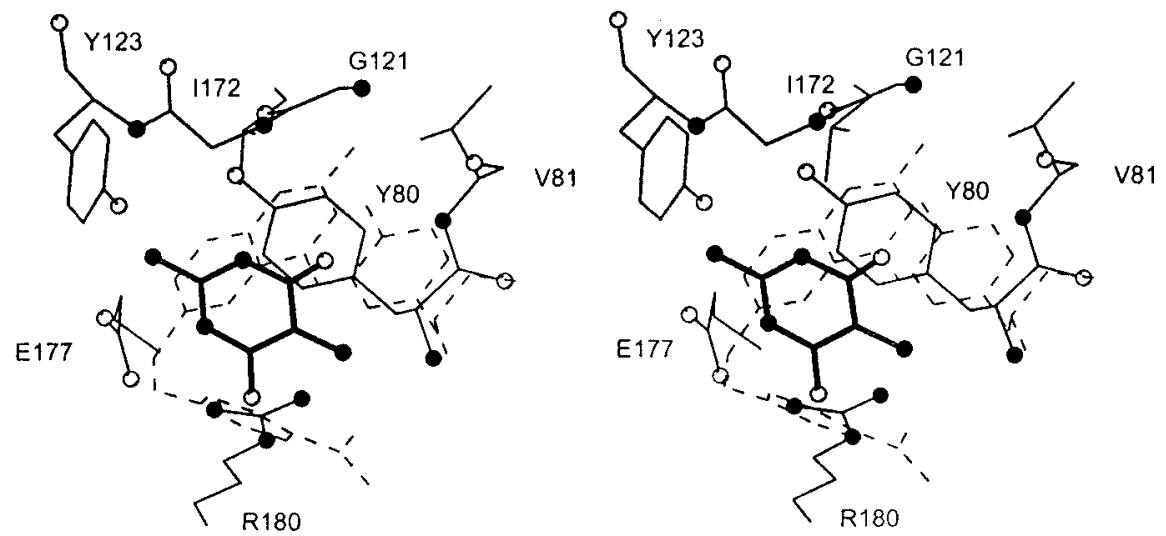

Figure 2. Superposition of the PTA RTA active site complex with the 2,5-diamino-4,6-dihydroxypyrmidine-RTA complex. The inhibitor is shown with bold bonds. Nitrogen atoms are shown as black spheres and oxygen as open spheres. Unlike PTA and other adenine analogues, the pyrimidine ring does not displace the side chain of Tyr 80 from its apoenzyme conformation and instead stacks against the side chain of Tyr 80 in its closed conformation. PTA and the displaced conformation of Tyr 80 are shown in dashed lines for comparison.
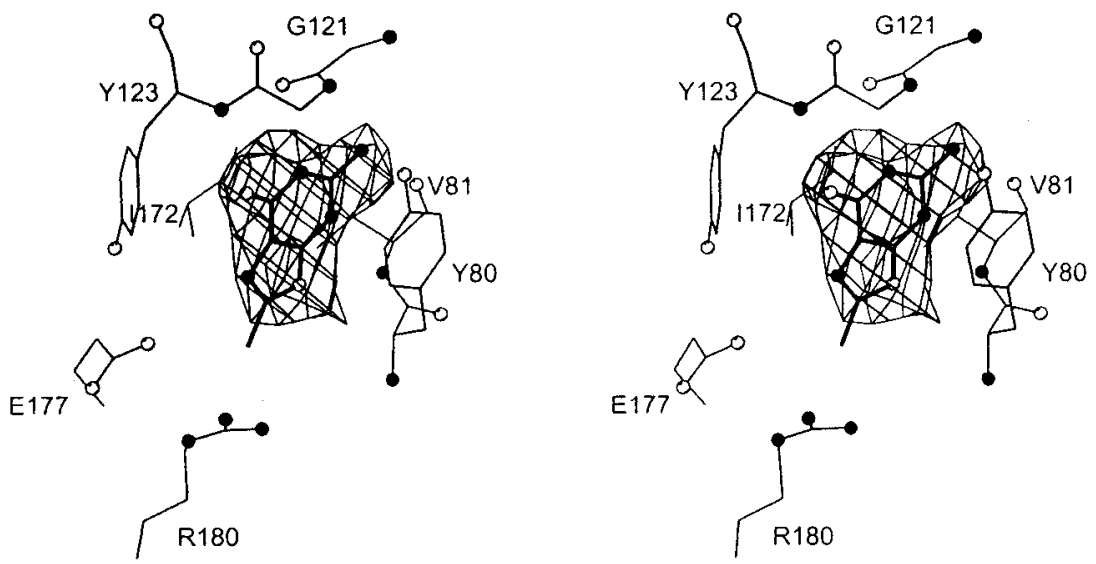

Figure 3. Electron density for 8-methyl-9-oxoguanine complexed to RTA. Omit density was calculated with amplitudes $\mathrm{F}_{\text {observed }}$ minus $F_{\text {calculated }}$ and phases from the refined protein in which Tyr 80 has been displaced to form the normal substrate binding site. The inhibitor is shown with bold bonds. Nitrogen atoms are shown as black spheres and oxygen as open spheres.

clash with the amido hydrogen of Val 81. As a consequence, RTA binds the pterin(3) tautomer with the hydrogen on N1, which it donates in a hydrogen bond to the carbonyl oxygen of Gly 121, as shown in Figure 4. The cost of this rearrangement is more than compensated for by the formation of the hydrogen bond. ${ }^{23}$

In the binding of 90G, no such tautomerization is required because the low-energy form has the hydrogen already at N1 (using guanine nomenclature, which differs from pterin nomenclature) available to donate a bond to 0121 . The novel orientation of 90G also brings the carbonyl oxygen into a position to accept a hydrogen bond from the amido group of Tyr 123, an interaction not seen in PTA. In PTA, Arg 180 donates two hydrogen bonds to the exocyclic oxygen at position 4 and to the ring nitrogen at position 5. The $90 \mathrm{G}$ orientation re 
A.

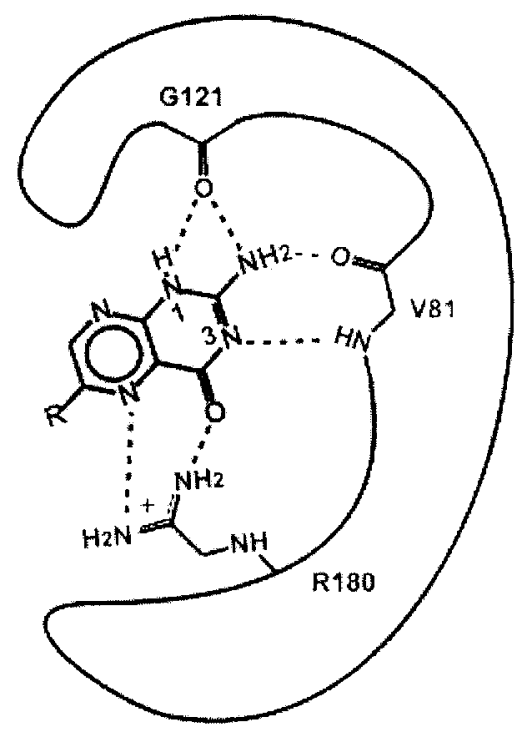

B.

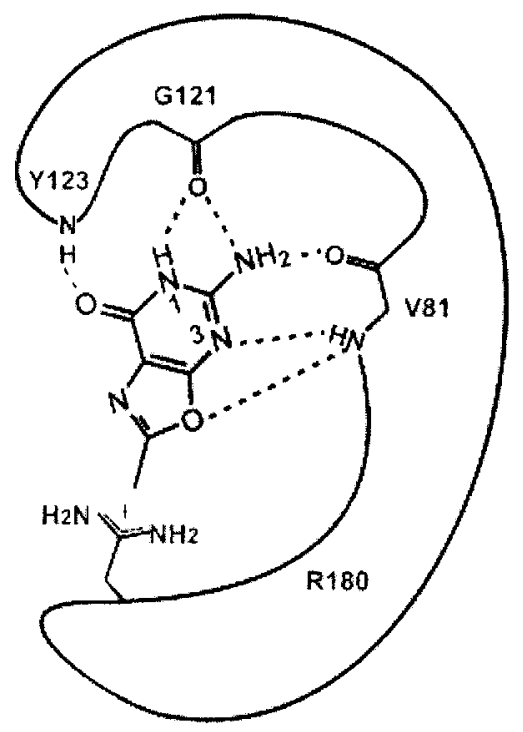

Figure 4. Comparison of pterin of PTA (A) and 8-methyl-9-oxoguanine binding to the active site of RTA. Hydrogen bonds are indicated with dashed lines. The labeled N 1 and N3 positions of the two heterocycles reflect the different nomenclature for pterin (A) and guanine (B).
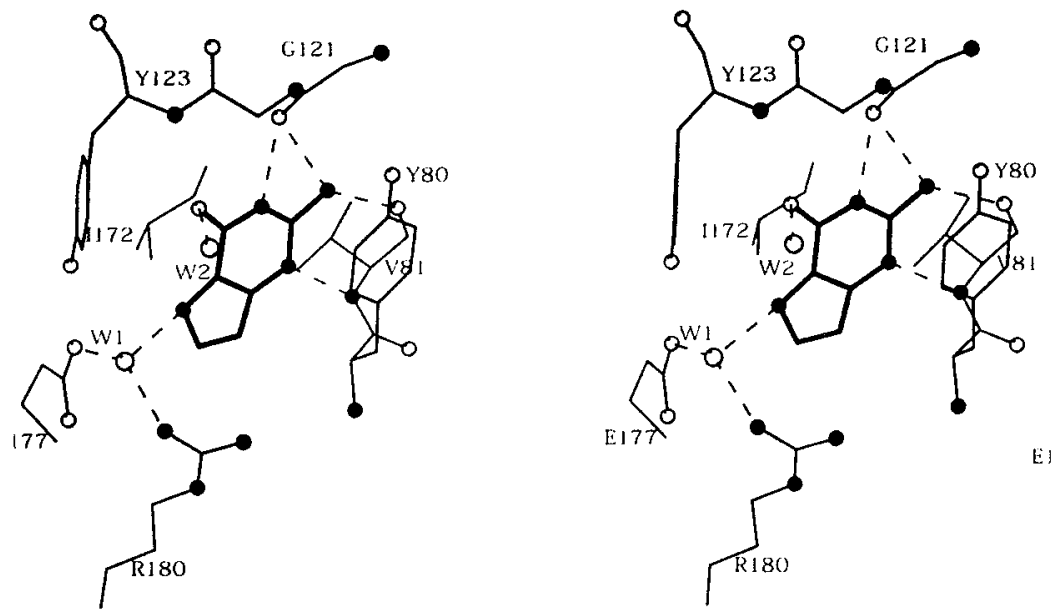

Figure 5. Stereogram of the 9-deazaguanine complex with RTA. The inhibitor is shown with bold bonds. Nitrogen atoms are shown as black spheres and oxygen as open spheres. Hydrogen bonds are indicated with dashed lines.

quires the side chain of Arg 180 to rotate slightly and allows only one bond to be formed to the ring oxygen at position 9.

If 90G were oriented like PTA, and if the compound tautomerized to a form like guanine(4), ${ }^{23}$ it would seem that the same number of hydrogen bonds could be made as are made in the observed form. However, the strength of these hypothesized interactions is difficult to estimate and compare to those bonds actually observed. It can only be assumed that the unexpected orientation is energetically more favorable than a pterin-like orientation by a subtle amount; it may be that that the difference is simply the cost of the tautomerization.

We also solved the X-ray structures of the 7DG and 9DG complexes with RTA to see if they would bind like the pterins or like 8-methyl-9-oxoguanine. Despite their differing pattern of hydrogen bonding groups, both compounds adopted a conformation like 90G in the crystal. The binding is shown for 9DG in Figure 5. In this structure two water molecules make additional interactions with the inhibitor, which were not present in the 90G structure. In the 7DG complex (not shown) N9 of 7DG donates a hydrogen to the backbone carbonyl of Ala 79, an interaction not seen in other ligand complexes with RTA.

Future design efforts will focus on adding pendant groups to a 9DG platform. These pendant groups, correctly oriented on an optimized scaffold heterocycle, will increase the binding of these compounds to provide more reasonable inhibition values. We investigated the binding of several 7DG-based structures shown in Table 1 to determine the preferable position for pendants to be attached. On the basis of the PTA structure and earlier predictions of guanine binding to RTA, the site of the p-aminobenzoic acid (PABA) moiety linkage to pterin position 6 in PTA would be roughly superimposed with position 8 of a guanine pendant. It would seem to be sterically favored to add a linker on position 8 rather than position 7, given the predicted proximity of Arg 180 to position 7. However, 9OG, 7DG, and 9DG all bind in an orientation that places position 8 in van der Waals 
Table 3. Comparison of Inhibitors against RTA and Stx $1 A 1$

\begin{tabular}{|c|c|c|c|}
\hline $2 \mathrm{D}$ Structure & Name & $\begin{array}{c}\mathrm{RTA} \\
\mathrm{C}_{50}\end{array}$ & $\begin{array}{c}\text { Stx1A1 } \\
\mathrm{IC}_{50}\end{array}$ \\
\hline & Pteroic acid & $0.6 \mathrm{mM}$ & $0.6 \mathrm{mM}$ \\
\hline & $\begin{array}{c}\text { 8-methyl-9- } \\
\text { oxoguanine }\end{array}$ & $0.4 \mathrm{mM}$ & $1.0 \mathrm{mM}$ \\
\hline
\end{tabular}

contact with Arg 180. Interestingly, the I $\mathrm{C}_{50}$ values for the near-isomeric compounds N-4-[2-(2-amino-4(3H)oxo-7H-pyrrol o[2,3-d]pyrimidin-6-yl )ethyl]benzoic acid and 5-(4-carboxyphenylaminomethyl)2-octanoylaminopyrrolo[2,3-d]pyrimi dine-4(3H)-one shown in Table 1 are 0.6 and $0.7 \mathrm{mM}$. The fact that both molecules bind with essentially the same affinity suggests that both positions 7 and 8 are feasible for further design efforts. However, if one considers the $\mathrm{IC}_{50}$ data, PTA binding, the predicted binding of guanine-based compounds, and the observed binding of 9OG, 7DG, and 9DG to RTA as a whole, it seems likely that guanine-based molecules appended at position 8 will revert to the PTA binding mode. Future studies will investigate the inhibition of, and binding to, RTA by 9DG derivatives with larger pendants attached to position 8.

Several RTA inhibitors were also tested against Shiga toxin. As described in the Experimental Section, Stx1A1, normally inhibitory to bacterial ribosomes, ${ }^{28}$ was produced in high yield from a new intein fusion. The results of the inhibition studies are shown in Table 3. Their $I_{50}$ val ues are in agreement with those for RTA, within the error associated with the activity assay. This confirms the prediction that competitive RTA inhibitors can be as effective against Shiga toxin.

\section{Experimental Section}

1. Synthesis. All evaporations were carried out in vacuo with a rotary evaporator. Melting points were determined on a Thomas-Hoover capillary melting point apparatus and are uncorrected. Unless otherwise noted, ${ }^{1} \mathrm{H}$ and ${ }^{13} \mathrm{C}$ NMR spectra were determined in DMSO- $\mathrm{d}_{6}$ on a Varian spectrometer operating at 300 and $75.47 \mathrm{MHz}$, respectively. The chemical shift values are expressed in ppm relative to tetramethylsilane as internal standard. All mass spectra were obtained by chemical ionization using methane as the ionizing gas. Thin-layer chromatography (TLC) was performed on Merck silica gel 60 $\mathrm{F}_{254}$ plates with a fluorescent indicator. Proportions of solvents used for TLC are by volume. All solvents and reagents were purchased from Aldrich Chemical Co. and Fisher Scientific and were used as received. 2,6-Diamino-4-hydroxypyrimidine, 6-hydroxy-2,4,5-triaminopyrimidine, guanine, 2-amino-4-hydroxypyrimidine, 2-amino-6-hydroxy-8-mercaptopurine, and xanthine were purchased from Aldrich Chemical Company. 2-Amino-4,6-di hydroxy-5-methyl pyrimidine and 4-amino-6-hydroxy2-methyl pyrimidine dihydrate were purchased from Acros. 2,5Diamino-4-hydroxypyrimidine, ${ }^{29}$ 2,5-diamino-4,6-dihydroxypyrimidine, ${ }^{30}$ 9-deazaguanine, ${ }^{31}$ 2-amino-6-methyl-3,4-dihydro4-oxo-7H-pyrrolo[2,3-d]pyrimidine, and N-4-[2-(2-amino-4(3H)oxo-7H-pyrrolo[2,3-d]pyrimidin-6-yl)ethyl ]benzoic acid ${ }^{32}$ were prepared according to the literature procedures.
2-Amino-6-methyl-3,4-dihydro-4-oxo-7H-pyrrolo[2,3-d]pyrimidine was prepared by a slight modification of the route reported by Gangjee ${ }^{33}$ and Secrist. ${ }^{34}$

2,6-Diaminothiazolo[4,5-d]pyrimidin-7(6H)-one was pre pared by a slight modification of the method of Sircar and coworkers. 35

2-Amino-3,4-dihydro-4-oxo-7H-pyrrolo[2,3-d]-pyrimidine $^{36}$ was prepared by an improved, one-step procedure. To a stirred solution of DMF $(240 \mathrm{~mL})$ and water $(40 \mathrm{~mL})$ at room temperature were added 2,4-diamino-6-hydroxypyrimidine $(12.6 \mathrm{~g}, 0.1 \mathrm{~mol})$ and $\mathrm{NaOAc}(8.2 \mathrm{~g}, 0.1 \mathrm{~mol})$. After the reaction mixture became homogeneous, $50 \%$ aqueous $\alpha$-chloroacetaldehyde $(15.7 \mathrm{~g}, 0.1 \mathrm{~mol})$ was added all at once. The reaction mixture was stirred at room temperature for 2 days, and the solvent was evaporated under vacuum. The residue was triturated with $10 \mathrm{~mL}$ of water, cooled, and filtered. The solid was purified over silica gel col umn chromatography to afford $10.8 \mathrm{~g}(72 \%)$ of a buff-colored solid whose ${ }^{1 \mathrm{H}}$ and ${ }^{13} \mathrm{C}$ NMR spectra matched those reported.

5-Amino-2-methyl-6H-oxazolo[5,4-d]pyrimidin-7-one (3). Sodium pieces $(0.575 \mathrm{~g}, 25 \mathrm{mmol}$ ) were added to ethanol (50 $\mathrm{mL}$ ) under argon with stirring. After all the sodium had reacted, guanidine hydrochloride $(2.38 \mathrm{~g}, 25 \mathrm{mmol})$ was added all at once, and the reaction mixture was stirred further for $10 \mathrm{~min}$. The reaction mixture was heated to reflux, and during this time di ethylacetamido malonate ${ }^{37}(5.43 \mathrm{~g}, 25 \mathrm{mmol})$ was added. After $2 \mathrm{~h}$, ethanol $(50 \mathrm{~mL})$ was added, and the reaction mixture was refluxed for an additional $12 \mathrm{~h}$. The reaction mixture was allowed to cool and was filtered. The residue was washed with ethanol and chloroform and was dried. The resulting solid was dissolved in water $(25 \mathrm{~mL})$ and was precipitated by the addition of $50 \%$ hydrochloric acid. The solution was filtered, and the solid was washed with water and acetone and then was dried under vacuum to afford 5-acetylamino-2-amino-4,6-dihydroxypyrimidine ${ }^{38}$ as a white solid $(4.1 \mathrm{~g}, 89 \%) ; \mathrm{mp}>300{ }^{\circ} \mathrm{C}$. ${ }^{1} \mathrm{H}$ NMR $\left(300 \mathrm{MHz}, \mathrm{D}_{2} \mathrm{O}\right): \delta$ 1.88 (s). ${ }^{13} \mathrm{C}$ NMR (75 MHz, DMSO-d 6 ): $\delta 21.9$ (q), 92.6 (s), 154.5 (s), 168.2 (s), 174.9 (s). HRMS (Cl) calcd for $\mathrm{C}_{6} \mathrm{H}_{9} \mathrm{~N}_{4} \mathrm{O}_{3}$, 185.0675; found 185.0668. The 5-acetylamino-2-amino-4,6dihydroxypyrimidine (184 $\mathrm{mg}, 1 \mathrm{mmol}$ ) was taken in a sublimation apparatus and was heated slowly to $280-300{ }^{\circ} \mathrm{C}$ under vacuum for $14 \mathrm{~h}$. The resulting sublimed solid was dissolved in methanol and purified by silica gel chromatography to afford the product $\mathbf{3}$ as a pale-yellow solid $(22.7 \mathrm{mg}$, $14 \%) ; \mathrm{mp}>300{ }^{\circ} \mathrm{C} .{ }^{1} \mathrm{H}$ NMR: $\delta 2.38(\mathrm{~s}, 3 \mathrm{H}), 6.85$ (br s, 2H), 11.0 (br s, 1H). ${ }^{13} \mathrm{C}$ NMR: $\delta 13.8$ (q), 111.2 (s), 154.6 (s), 155.6 (s), 156.1 (s), 166.4 (s). HRMS calcd for $\mathrm{C}_{6} \mathrm{H}_{7} \mathrm{~N}_{4} \mathrm{O}_{2}\left(\mathrm{MH}^{+}\right)$, 167.0569; found, 167.0573 .

3-Aminopyridothiadiazine (5). An intimate mixture of 3-aminopyridine-2-sulfonamide ${ }^{39}(300 \mathrm{mg}, 1.73 \mathrm{mmol}$ ) and guanidine carbonate $(624 \mathrm{mg})$ was heated at $180-190{ }^{\circ} \mathrm{C}$ for $1.5 \mathrm{~h}$. The brown mass was dissolved in boiling water, and the solution was acidified to $\mathrm{pH} 4$ by $1 \mathrm{~N}$ hydrochloric acid. After removal of the solvent, the residue was purified by silica gel col umn chromatography to afford the product as a white solid (105 mg, 31\%); $\mathrm{mp}>250{ }^{\circ} \mathrm{C} .{ }^{1} \mathrm{H}$ NMR: $\delta 7.12(\mathrm{~s}, 2 \mathrm{H})$, $7.59(\mathrm{~m}, 2 \mathrm{H}), 8.40(\mathrm{~m}, 1 \mathrm{H}), 10.80(\mathrm{~s}, 1 \mathrm{H}) .{ }^{13} \mathrm{C} N M R: \delta 125.2$, 127.4, 132.5, 138.9, 145.0, 150.9. Anal. $\left(\mathrm{C}_{6} \mathrm{H}_{6} \mathrm{~N}_{4} \mathrm{O}_{2} \mathrm{~S}\right) \mathrm{H}, \mathrm{N}, \mathrm{S}$; $C$ calcd 36.36 , found 36.97 .

2-Amino-5-(4-carboxyphenylaminomethyl)pyrrolo[2,3d]pyrimidin-4(3H)-one (8). A suspension of 5-(dibenzylaminomethyl)-2-octanoylaminopyrrolo[2,3-d]pyrimidin-4(3H )one ${ }^{40}(220 \mathrm{mg}, 0.412 \mathrm{mmol}$ ) and methyl 4-aminobenzoate (331.2 mg, $2.06 \mathrm{mmol}$ ) in $1.5 \mathrm{~mL}$ of 1:1 MeOH/THF was heated at $70^{\circ} \mathrm{C}$ for $24 \mathrm{~h}$ with stirring in a sealed tube. The reaction mixture was cooled to room temperature and was evaporated to dryness. The residue was purified by silica gel column chromatography $\left(95: 5 \mathrm{CHCl}_{3} / \mathrm{MeOH}\right)$ to afford 5-(4'-carbomethoxyphenylaminomethyl)-2-octanoylaminopyrrolo[2,3-d]pyrimidin-4(3H)-one as an off-white solid (98 $\mathrm{mg}, 54 \%)$. TLC $\mathrm{R}_{\mathrm{f}}=0.39\left(90: 10 \mathrm{CHCl}_{3} / \mathrm{MeOH}\right) .{ }^{1} \mathrm{H} \mathrm{NMR}\left(\mathrm{MeOH}-\mathrm{d}_{4}\right): \delta 7.66$ $\left(\mathrm{d}, 10 \mathrm{~Hz}, 2 \mathrm{H}, \mathrm{C}_{6} \mathrm{H}_{4}\right), 6.88(\mathrm{~s}, 1 \mathrm{H}, 6-\mathrm{CH}), 6.77(\mathrm{t}, 6 \mathrm{~Hz}, 1 \mathrm{H}$, 2-NH), $6.64\left(\mathrm{~d}, 10 \mathrm{~Hz}, 2 \mathrm{H}, \mathrm{C}_{6} \mathrm{H}_{4}\right), 4.39\left(\mathrm{bd}, 2 \mathrm{H}, 5-\mathrm{CCH}_{2} \mathrm{NH}\right)$, $3.72\left(\mathrm{~s}, 3 \mathrm{H}, \mathrm{CO}_{2} \mathrm{CH}_{3}\right), 2.42\left(\mathrm{t}, 2 \mathrm{H}, \mathrm{C}_{7} \mathrm{H}_{15}\right), 1.56\left(\mathrm{bt}, 2 \mathrm{H}, \mathrm{C}_{7} \mathrm{H}_{15}\right)$, 
1.26 (bs, 8H, $\mathrm{C}_{7} \mathrm{H}_{15}$ ), 0.90 (bt, 3H, C7H 15). HRMS calcd for $\left(\mathrm{C}_{23} \mathrm{H}_{29} \mathrm{~N}_{5} \mathrm{O}_{4}\right), 439.221$ 955; found, 439.221 475. To a solution of this methyl ester (103 mg, $0.234 \mathrm{mmol}$ ) in $500 \mu \mathrm{L}$ of $\mathrm{EtOH}$ and $2 \mathrm{~mL}$ of $\mathrm{H}_{2} \mathrm{O}$ was added $5 \mathrm{M} \mathrm{KOH}(117.25 \mu \mathrm{L}, 0.586 \mathrm{mmol}$ ). This mixture was stirred for $48 \mathrm{~h}$, at which time the reaction became homogeneous. The solution was evaporated, the residue was dissolved in $\mathrm{H}_{2} \mathrm{O}$, and the $\mathrm{pH}$ was adjusted to 7 with $\mathrm{AcOH}$. The $\mathrm{H}_{2} \mathrm{O}$ was removed in vacuo, and $\mathrm{MeOH}$ was added to the residue. The mixture was centrifuged, and the $\mathrm{MeOH}$ was removed. $\mathrm{M}$ ore $\mathrm{MeOH}$ was added; this process was carried out three more times. The $\mathrm{MeOH}$ fractions were combined and evaporated, and the residue was applied to a flash silica gel chromatography column and eluted with 90: 9:1 $\mathrm{CHCl}_{3} / \mathrm{MeOH} / \mathrm{AcOH}$ to afford the product as a yellow solid (66.2 mg, 95\% yield). TLC $\mathrm{R}_{\mathrm{f}}=0.09\left(90: 9: 1 \mathrm{CHCl}_{3} / \mathrm{MeOH} /\right.$ $\mathrm{AcOH}) .{ }^{1} \mathrm{H} N M R\left(\mathrm{D}_{2} \mathrm{O}\right): \delta 7.64\left(\mathrm{~d}, 10 \mathrm{~Hz}, 2 \mathrm{H}, \mathrm{C}_{6} \mathrm{H}_{4}\right), 6.79(\mathrm{~d}$, $\left.10 \mathrm{~Hz}, 2 \mathrm{H}, \mathrm{C}_{6} \mathrm{H}_{4}\right), 6.61(\mathrm{~s}, 1 \mathrm{H}, 6-\mathrm{CH}), 4.33\left(\mathrm{~s}, 2 \mathrm{H}, 5-\mathrm{CCH}_{2} \mathrm{NH}\right)$. Anal. $\left(\mathrm{C}_{14} \mathrm{H}_{13} \mathrm{~N}_{5} \mathrm{O}_{3}+\mathrm{H}_{2} \mathrm{O}\right) \mathrm{C}, \mathrm{H}, \mathrm{N}$.

2. RTA Expression and RTA/Inhibitor in Vitro Activity. Recombinant RTA was overexpressed in E. coli as described. ${ }^{41}$ The activity of various RTA inhibitors was determined by an in vitro protein synthesis assay using Artemia salina ribosomes as described. ${ }^{41,22} \mathrm{M}$ ost inhibitors were solubilized in $0.045 \mathrm{~N} \mathrm{NaOH}$ prior to addition to toxin-containing solutions. The ligand/toxin sample was diluted 5-fold upon addition to buffered ribosomes. The residual base did not alter the final $\mathrm{pH}$ of the reaction, $\mathrm{pH} 7.6$, and did not affect protein synthesis. The final concentration of RTA was $2 \mathrm{nM}$ for all assays. The concentration of ribosomes was typically $0.3 \mu \mathrm{M}$.

3. Crystallization of RTA.Inhibitor Complexes. RTA monoclinic crystals were grown for the purpose of studying inhibitor binding to the enzyme. ${ }^{42,17}$ Briefly, $30 \mu \mathrm{L}$ of protein at $2.2-2.4 \mathrm{mg} / \mathrm{mL}$ in the mother liquor $(75 \mathrm{mM}$ Tris- $\mathrm{HCl}, \mathrm{pH}$ 8.9, $10 \mathrm{mM} \mathrm{BME}, 1 \mathrm{mM}$ EDTA, 4.1\% poly(ethylene glycol) MW 8000 (PEG 8000)) was suspended over $200 \mu \mathrm{L}$ of mother liquor at $4{ }^{\circ} \mathrm{C}$. Microseeds were transferred to the sitting drop for nucleation. The compounds 5-amino-2-methyl-6H-oxooxazolo[5,4-d]pyrimidin-7-one (8-methyl-9-oxoguanine) and 2,5-diamino-4,6-dihydroxypyrimidine were cocrystallized under native RTA monoclinic crystal conditions with a final ligand concentration of 4 and $10 \mathrm{mM}$, respectively. The compound 7-deazaguanine was solubilized in $0.033 \mathrm{~N} \mathrm{NaOH}$. A total of $5 \mu \mathrm{L}$ of the ligand solution was added to a $25 \mu \mathrm{L}$ of RTA crystal drop for a 4-day soak. The final concentration of ligand was estimated to be $4 \mathrm{mM}$. The inhibitor 9DG was cocrystallized under RTA monoclinic conditions. A total of $5 \mu \mathrm{L}$ of 9DG in $0.045 \mathrm{~N} \mathrm{NaOH}$ was added to $25 \mu \mathrm{L}$ of mother liquor to give an estimated $4 \mathrm{mM}$ final concentration of ligand.

4. X-ray Data Collection and Structure Determination. Diffraction data were collected on a Rigaku Raxis IV area detector. X-rays were generated by a Rigaku RU 200 rotating anode generator operated at $50 \mathrm{mV}, 100 \mathrm{~mA}$. Data were collected at room temperature for all crystals except RTA complexed with 8-methyl-9-oxoguanine. That crystal was soaked for $5 \mathrm{~min}$ in the mother liquor containing 15-25\% PEG 8000 and was transferred to paratone oil. After removal of surface-bound water, the crystal was flash-frozen in liquid nitrogen and mounted in a nitrogen cold stream. The program DENZO was used to process the diffraction images, and SCALEPACK was used to reduce the data. ${ }^{43}$ The starting model used for molecular replacement was the monoclinic crystal form of recombinant RTA. ${ }^{17}$ The RTA-2,5-diamino-4,6dihydroxypyrimidine cocrystal was triclinic with $a=42.07 \AA$, $\mathrm{b}=65.95 \AA, \mathrm{c}=50.81 \AA, \alpha=93.90^{\circ}, \beta=112.4^{\circ}$, and $\gamma=$ $84.43^{\circ}$. A molecular replacement solution was found with two monomers in the asymmetric unit using EPMR (Kissinger and Gehlhaar, Agouron Pharmaceuticals, Inc.). XPLOR was used for model refinement and generating Fourier maps with amplitudes $F_{\text {observed }}\left(F_{o}\right)$ minus $F_{\text {calculated }}\left(F_{c}\right)$ and $2 F_{o}-F_{c .}{ }^{44} \mathrm{O}$ was used for model building. ${ }^{45}$

5. Shiga-like Toxin Type 1 A Chain 1 (Stx1A1) Cloning, Expression, and Purification. Cloning of Stx1A1. A Stx1A1 gene was constructed with three histidines added to the naturally occurring three histidines at the $C$ terminus. ${ }^{15,46}$
The hexa-His tagged protein was initially purified by nickel affinity chromatography. Because of unsatisfactory expression levels $(0.1 \mathrm{mg} / \mathrm{L})$, StXA1 was cloned into an intein-fusion vector pCYB2 (NEB). The intein protein was engineered on the $C$ terminus of the Stx $1 \mathrm{~A} 1$ clone retaining the hexa-His tag.

Expression of Stx1A1. To avoid premature expression of Stx1A1, the protein was expressed in BL21 salt inducible (BL21-SI) cells (Life Technologies). The cells were made competent by the $\mathrm{RbCl}_{2}$ method (http://www.nwfsc.noaa.gov/ protocol s/rbcl.html) and were transformed with the StxlA1intein plasmid. The transformed cells were then plated on LBAMP plates with no salt ( $L B O N-A M P)$ to avoid induction of protein expression. The plates were incubated overnight at 37 ${ }^{\circ} \mathrm{C}$. A single col ony was picked for inoculation of $10 \mathrm{~mL}$ cultures in LBON-AMP media; the AMP concentration used throughout the procedure was $100 \mu \mathrm{g} / \mathrm{mL}$. The cultures were grown overnight at $30{ }^{\circ} \mathrm{C}$ to a density of about $0.5 \mathrm{OD}_{600}$ and were added to $500 \mathrm{~mL}$ of LBON-containing AMP. After $2 \mathrm{~h}$, protein expression was induced by adding $0.3 \mathrm{M} \mathrm{NaCl}$. The cells were harvested $3 \mathrm{~h}$ later by centrifugation at $4068 \mathrm{~g}$ in a GSA Sorvall rotor for $10 \mathrm{~min}$. Cells were resuspended in column buffer (20 $\mathrm{mM}$ Tris- $\mathrm{HCl}, \mathrm{pH} 8.0,0.5 \mathrm{M} \mathrm{NaCl}, 0.1 \mathrm{mM}$ EDTA) and broken twice by passage through a French Press cell (SLM Aminco Urbana, IL) at 1000 psi. Lysed cells were centrifuged at $94000 \mathrm{~g}$ for $1 \mathrm{~h}$ in a $42.1 \mathrm{Ti}$ rotor (Beckman).

Purification of Stx1A1. The fusion protein was purified by affinity chromatography. The supernatant was loaded onto a preequilibrated chitin-binding domain (CBD) and $5 \mathrm{~mL}$ column (NEB). Column washing, intein on-column cleavage, and elution of the Stx1A1 protein was done according to the manufacturer's specifications. The highly pure tagfree protein was expressed at approximately 5-15 mg/L. Pure fractions were assessed by SDS-PAGE. Stx1A1 was then dialyzed into $10 \mathrm{mM}$ Tris, $\mathrm{pH}$ 7.5, and $75 \mathrm{mM} \mathrm{NaCl}$.

Acknowledgment. This work was supported by Grant GM 30048 from the National Institutes of Health and by grants from the Foundation for Research and the Welch Foundation.

\section{References}

(1) Olsnes, S.; Pihl, A. Toxic Lectins and Related Proteins. In The Molecular Action of Toxins and Viruses; Cohen, P., Van Heynigen, S., Eds.; Elsevier Biomedical Press: New York, 1982; pp 52-105.

(2) Endo, Y.; Tsurugi, K. RNA N-glycosidase activity of ricin A-chain. J. Biol. Chem. 1987, 262, 8128-8130.

(3) Endo, Y.; Tsurugi, K. The RNA N-glycosidase activity of ricin A-chain: the characteristics of the enzymatic activity of ricin A-chain with ribosomes and with rRNA. J. Biol. Chem. 1988, 263, 8735-8739.

(4) Lord, J. M.; Roberts, L. M.; Robertus, J. D. Ricin: structure, mode of action, and some current applications. FASE B J . 1994, 8, 201-208.

(5) Robertus, J. D.; Monzingo, A. F. The Structure of Ribosome Inactivating Proteins from Plants. In Protein Toxin Structure; Parker, M., Eds.; Landes, R. G.: Austin, TX, 1996; pp 253-270.

(6) Rich, V. Murderous experiments of Stalin's police chief. New Sci. 1992, 135, 8.

(7) Remnick, D. KGB plot to assassinate Solzhenitzen reported. Washington Post 1992, April 21, D1.

(8) de Fiebre, C. Two convicted of possessing deadly poison. Minneapolis Star-Tribune 1995, March 1, 1B.

(9) Murphy, K. Man gets prison time for possessing toxin. MilwaukeeJ. Sentinel 1999, May 21, 2.

(10) Lowe, P. Toxin threat alleged. Ex-Boulder man arrested in Fla. Denver Post Staff 1999, November 8, B5.

(11) Shiga, K. Ueber den Dysenterie-bacillus (Baccillus dysenteriae). Zentral bl. Bakteriol. Orig. 1898, 24, 913-918.

(12) O'Brien, A. D.; Tesh, V. L.; Donohue-Rolfe, A.; J ackson, M. P.; Olsnes, S.; Sandvig, K.; Lindberg, A. A.; Keusch, G. T. Shiga Toxin: Biochemistry, Genetics, Mode of Action, and Role in Pathogenesis. In Pathogenesis of Shigel losis; Sansonetti, P. J ., Ed.; Springer-Verlag: Berlin, 1992; pp 65-94.

(13) Fraser, M. E.; Chernaia, M. M.; Kozlov, Y. V.; J ames, M. N. G. Crystal structure of the holotoxin from Shigella dysenteriae at $2.5 \AA$ resolution. Struct. Biol. 1994, 1, 59-64.

(14) Katzin, B.J.; Collins, E. J .; Robertus, J . D. The structure of ricin A chain at $2.5 \AA$. Proteins 1991, 10, 251-259. 
(15) Suh, J. K.; Hovde, C. J .; Robertus, J. D. Shiga toxin attacks bacterial ribosomes as effectively as eucaryotic ribosomes. Biochemistry 1998, 37, 9394-9398.

(16) Montfort, W.; Villafranca, J . E.; Monzingo, A. F.; Ernst, S. R.; Katzin, B.; Rutenber, E.; Nuyhen, H. X.; Hamlin, R.; Robertus J. D. The three-dimensional structure of ricin at $2.8 \AA$. J . Biol. Chem. 1987, 262, 5398-5403.

(17) Mlsna, D.; Monzingo, A. F.; Katzin, B. J .; Ernst, S.; Robertus, . D. The structure of recombinant ricin A chain at 2.3 A. Protein Sci. 1993, 2, 429-435.

(18) Weston, S. A.; Tucker, A. D.; Thatcher, D. R.; Derbyshire, D. J .; Pauptit, R. A. X-ray structure of recombinant ricin A-chain at 1.8 A resolution. J. Mol. Biol. 1994, 244, 410-422.

(19) Frankel, A.; Welsh, P.; Richardson, J .; Robertus, J . D. The role of arginine 180 and glutamic acid 177 of ricin toxin A chain in the enzymatic inactivation of ribosomes. Mol. Cell. Biol. 1990, $10,6257-6263$

(20) Kim, Y. S.; Robertus, J . D. Analysis of several key active site residues of ricin $A$ chain by mutagenesis and X-ray crystallography. Protein Eng. 1992, 5, 775-779.

(21) Monzingo, A. F.; Robertus, J. D. X-ray analysis of substrate analogues in the ricin A-chain active site. J . Mol. Biol. 1992, 227, 1136-1145.

(22) $Y$ an, $X$ : Hollis, T: Svinth, M: Day, P : Monzingo, A. F : Milne G. W. A.; Robertus, J . D. Structure-based identification of a ricin inhibitor. J . Mol. Biol. 1997, 266, 1043-1049.

(23) Yan, X.; Day, P.; Hollis, T.; Monzingo, A. F.; Schelp, E.; Robertus J. D.; Wang, S.; Milne, G. W. Recognition and interaction of small rings with the ricin A chain binding site. Proteins 1998, 31, 3341.

(24) Turchi, I.; Maryanoff, C. A. A New Synthesis of Oxazolo[5,4-d]pyrimid-7-ones Synthesis 1983, 10, 837-839.

(25) Temple, C., J r.; Smith, B. F.; Montgomery, J . A. Preparation of 2,5-Diamine-4,6-dichloropyrimidine. J . Org. Chem. 1975, 40, 3141-3142.

(26) Pirotte, B.; de Tullio, P.; Lebrun, P.; Antione, M. H.; Fontaine, J .; Masereel, B.; Schynts, M.; Dupont, L.; Herchuelz, A.; Delarge, J . 3-(Alkylamino)-4H-pyrido[3,4-e]-1,2,4-thiadiazine 1,1-Dioxides as Powerful Inhibitors of Insulin Release from Rat Pancreatic B-Cells: A New Class of Potassium Channel Openers? J . Med. Chem. 1993, 36, 3211-3213.

(27) Seela, F : Chen, Y : Zulauf, M. Regioselectivity of the Mannich Reaction on Pyrrolo[2,3-d]pyrimidine Nucleosides Related to 7-Deaza-2'-deoxyadenosine of 7-Deaza-2'-deoxyguanosine. Synthesis 1997, 1067-1072.

(28) Zollman, T. M.; Austin, P. P.; J ablonski, P. E.; Hovde, C. J Purifcation of recombinant Shiga-like toxin type 1 Al fragment from Escherichia coli. Protein Expression Purif. 1994, 5, 291295.

(29) Kelley, J . L.; McLean, E. W. Synthesis and Antimicrohial Testing of 2-Amino-6-hydroxymethyl-4-(3H)pyrido[3,2-d]pyrimidinone. J . Heterocycl. Chem. 1981, 18, 671-673.

(30) Koppel, H. C.; Robins, R. K. Potential Purine Antagonists. XI Synthesis of Some 9-Aryl(alkyl)-2,6-disubstituted Purines. J . Am. Chem. Soc. 1958, 80, 2751-2755.

(31) Klein, R. S.; Lim, M.; Tam, S. Y. K.; Fox, J . J . New Synthesis of 5H-pyrrolo[3,2-d]pyrimidines via Pyrimido[5,4-c]pyridazines. J Org. Chem. 1978, 43, 2536-2539.
(32) Taylor, E. C.; Young, W. B.; Chaudhari, R.; Patel, H. H. Synthesis of a Regioisomer of $\mathrm{N}$-[4-[2-[2-Amino-4(3H)-oxo-7Hpyrrolo[2,3-d]pyrimidin-5-yl)ethyl ]benzoyl-L-glutamicadid(LY231514) An Active Thymidylate Synthase Inhibitor and Antitumor Agent. Heterocycles 1993, 36, 1897-1908.

(33) Gangjee, A.; Mavandadi, F.; Kislium, R. L.; Mcguire, J . J .; Queener, S. F. 2-Amino-4-oxo-5-substituted-pyrrolo[2,3-d]pyrimidines as Nonclassical Antifolate Inhibitors of Thymidylate Synthase. J . Med. Chem. 1996, 39, 4563-4568.

(34) Secrist, J . A., III; Liu, P. S. Studies Directed toward a Total Synthesis of Nucleoside Q. The Annulation of 2,6-Diaminopyrimidin-4-one with $\alpha$-Halocarbonyls To Form Pyrrolo[2,3-d] pyrimidines and Furo[2,3-d]pyrimidines. J . Org. Chem. 1978, 43, 3937-3941.

(35) Sircar, J . C.; Suto, M. J .; Scott, M. E.; Dong, M. K.; Gilbertson, R. B. Inhibitors of Human Purine Nucleoside Phosphorylase. Synthesis, Purine Nucleoside Phosphorylase Inhibition, and T-Cell Cytotoxicity of 2,5-Diaminothiazolo[5,4-d]pyrimidin-7(6H)one and 2,5-Diaminothiazolo[4,5-d]pyrimidin-7(6H)-one. Two Thio Isosteres of 8-Aminoguanine. J. Med. Chem. 1986, 29, 1804-1806.

(36) Davoll, J . Pyrrolo[2,3-d]pyrimidines. J . Chem. Soc. 1960, 131138.

(37) Zambito, A.J .; Howe, E. E. Diethyl acetamidomalonate. Organic Syntheses; Wiley: New York, 1973; Vol. V (Collective), pp 373375.

(38) Taylor, E. C.; Cain, C. K. The Hydrolysis of Amino Groups in Certain 2,4,5,6-Tetrasubstituted Pyrimidines. J . Am. Chem. Soc 1949, 71, 2281-2284.

(39) Lejeune, R.; Delarge, J .; Thunus, L. Preparation du Mercapto 3-pyridinesulfonamide-2. J . Pharm. Belg. 1984, 39, 217-224.

(40) Akimoto, H.; Imamiya, E : Hitaka, T.; Nomura, H.; Nishimura S. Synthesis of Queuine, the Base of Naturally Occurring Hypermodified Nucleoside (Queuosine), and Its Analogues. J. Chem. Soc., Perkin Trans. 1 1988, 1637-1644.

(41) Ready, M. P.; Kim, Y. S.; Robertus, J . D. Directed alteration of active site residues in ricin $A$ chain and implications for the mechanism of action. Proteins 1991, 10, 270-278.

(42) Robertus, J . D.; Piatak, M.; Ferris, R.; Houston, L. L. Crystallization of ricin A chain obtained from a cloned gene expressed in Escherichia coli. J. Biol. Chem. 1987, 262, 19-20.

(43) Otwinowski, Z.; Minor, W. Processing of X-ray Diffraction Data Collected in Oscillation Mode. Methods Enzymol. 1997, 276, 307-326.

(44) Brünger, A. T. X-PLOR. A System for X-ray Crystallography and NMR, version 3.1; Yale University Press: New Haven, CT, 1992.

(45) J ones, T. A.; Zou, J . Y.; Cowan, S. W.; Kjeldgaard, M. I mproved methods for building models in electron density maps and the location of errors in these models. Acta Crystallogr. 1991, 24, 946-950.

(46) Deresiewicz, R. L.; Austin, P. R.; Hovde, C. J. The role of tyrosine-114 in the enzymatic activity of the Shiga-like toxin I A-chain. Mol. Gen. Genet. 1993, 241, 467-473.

J M010186S 